\title{
Los unos y los otros: identidades en el cine chileno (1960-2014)
}

\section{Us and them: identities in Chilean cinema (1960-2014)}

\author{
Pablo Marín Castro ${ }^{1}$ \\ Universidad Diego Portales (Chile)
}

Recibido: 11-05-15

Aprobado: 05-06-15

\section{Resumen}

Durante el último medio siglo, el cine chileno argumental ha desplegado una gran variedad de ejemplos de adhesión y pertenencia a distintas categorías identitarias, individuales y colectivas, heredadas o voluntariamente asumidas. El presente ensayo se pregunta por los tipos humanos presentes en la producción fílmica y propone que es posible detectar y estudiar la presencia de espacios identitarios en el cine chileno, así como determinar el modo en que las identidades se ponen en juego cuando las contingencias políticas o el espíritu de una época cuestionan la inercia de grupos e individuos. Ello, en el contexto de un cuadro interpretativo mayor: la posibilidad de comprender diversos aspectos de la historia, la sociedad y la cultura chilenas a través del cine.

Palabras-clave: Historia de Chile, Cine chileno, Identidad, Cultura.

\footnotetext{
${ }^{1}$ (pmarincas@yahoo.com). Licenciado en Comunicación Social, Universidad de Chile, Periodista por la Universidad de Chile y Magíster en Historia c/m Historia de Chile en la misma Universidad. Entre sus publicaciones recientes destacan: "En el río aquel: el Mapocho, eje y frontera de Santiago" [en Gloria Camarero (ed.): Ciudades latinoamericanas en el cine. Madrid, Akal, 2015 (en proceso de publicación)]. "El desafío de Robert Rosenstone a nuestra idea de la historia" [en Robert A. Rosenstone: Cine y visualidad. Historización de la imagen contemporánea. Santiago, Ediciones U. Finis Terrae, 2013. Prólogo]; "Anotaciones - o apuntes- sobre las elites y el cine chileno", [en Revista $U D P, 09,2012$ ]; "Rodrigo Marín: Pertenencia e insatisfacción” [en Ascanio Cavallo y Gonzalo Maza (eds.); El novísimo cine chileno. Santiago, Uqbar, 2011], y "Mito e historia en La expropiación" [en Valeria de los Ríos e Iván Pinto (eds.): El cine de Raúl Ruiz. Fantasmas, simulacros y artificios. Santiago, Uqbar, 2010].
} 


\begin{abstract}
Over the past half century, plot-driven Chilean cinema has deployed a variety of examples of membership and belonging to different identities, individual and collective, inherited or voluntarily assumed. This essay asks about human types present in film and proposes that it is possible to detect and study the presence of identity spaces in Chilean cinema and determine how identities come into play when political contingencies or the spirit of an age question the inertia of groups and individuals. This is presented in the context of a larger interpretive framework: the ability to understand different aspects of history, society and Chilean culture through film.
\end{abstract}

Key-words: Chilean history, Chilean cinema, Identity, Culture.

Dentro de lo poco que en ese momento podía mostrar (12 largometrajes argumentales estrenados en toda la década anterior), para 1960 el cine chileno daba cuenta todavía de una diversidad de inquietudes asociadas a las tensiones campo-ciudad, sea oponiendo una pureza irreductible a la insensibilidad civilizatoria, o el atraso y la pobreza al progreso y el desarrollo. El tercer día del año señalado se estrenaba Un viaje a Santiago y otra historia empezaba a escribirse. Una historia que se ramifica hasta nuestros días y a la que, así y todo, cuesta tomarle la hebra.

Escrito y dirigido por Hernán Correa, el señalado filme ha sido descrito como "el último esfuerzo de idealización del medio rural en el cine chileno de los 60, una tradición que arrancaba desde sus mismos orígenes"2, y su trayecto, como un "círculo de los que han salido hacia la jungla de la modernidad para retornar al vergel familiar"3. Cuenta la historia de un grupo de habitantes de la ficticia localidad rural de Tunco que carecen de un camino decente para transportar sus productos. El que hay rompe las ruedas de las carretas y la situación ya no da para más, sobre todo considerando que hubo una promesa de campaña en este sentido por parte del candidato a diputado Beroa, que ganó en las últimas elecciones parlamentarias. Extrañado de este olvido, el cacique local, don Jenaro, organiza una delegación de siete personas para que se desplace a la capital y le haga presente su urgencia a Beroa. Eso sí, provistos de una gallina viva y un pastel de choclo, plato típico del Valle Central chileno, pues la inmutable sabiduría de don Jenaro -y su esposa- asume que nada conseguirán de un político si no le llevan un "engañito" que conquiste su estómago.

${ }^{2}$ Cf. Ascanio Cavallo. y Carolina Díaz: Explotados y benditos. Mito y desmitificación del cine chileno de los 60. Santiago, Uqbar, 2006, p. 42.

3 Ibid, p. 41.

Araucaria. Revista Iberoamericana de Filosofía, Política y Humanidades, año 17, no 34. Segundo semestre de 2015. Pp. 329-351. ISSN 1575-6823 e-ISSN 2340-2199 doi: 10.12795/araucaria.2015.i34.15 
La idea misma del bloqueo al progreso se inscribe en la frustración de los tunquinos, dentro de los cuales hay sin embargo muchos tipos humanos como para que el rotulo de lo "tradicional", en oposición al de lo "moderno", preste mayores servicios ${ }^{4}$. Entre quienes se quedan en el pueblo hay un sacerdote joven, cuyas conminaciones a la mesura y la sensatez no hacen más que apuntalar el respeto que la comunidad ya profesa a su investidura. También un poderoso terrateniente, ansioso de hacerse con las tierras de los pequeños propietarios y ajeno al afán de don Jenaro y del resto. Entre quienes literalmente se suben al tren a la capital, hay un profesor escolar que hace las veces de conciencia cívico-civilizatoria: trata de educar a los hijos de los campesinos contra el parecer del señalado terrateniente, al tiempo que apuesta por una solución "política" al tema del camino (hablar con el otro diputado de la circunscripción, que no les prometió nada, pero que ha de hacer su trabajo), lo que lo enfrenta directamente con don Jenaro por el liderazgo del grupo. Adicionalmente, su amor apenas disimulado por la sobrina de su adversario, Alicia, lo deja expuesto, debilitando su posición. La mujer, por su lado, viaja a la capital para encarar a un santiaguino que le prometió matrimonio y nada ha dicho desde entonces (haciendo creer a todo el mundo, eso sí, que va a afinar detalles de la boda).

La delegación parte de un territorio que no es necesariamente una reserva de pureza -la idealización de lo rural apenas se sostiene- y se enfrenta, llegados a la capital, a un espacio sombrío y desangelado ("nunca Santiago nos pareció más feo", se leyó en el semanario Écran). He ahí uno de los ítemes que hace al filme de Correa revelador e inaugural. En lo estilístico y en lo discursivo, la cinta expresa un final de la inocencia: lejana a toda estetización que autorice idealizar los lugares que exhibe, empuja a la mencionada Alicia a aceptar que el hombre al que había entregado su flor tenía ya mujer e hijo. En lo que toca a los tunquinos, y en especial a don Jenaro, el escabullimiento final del diputado Beroa materializa una decepción absoluta. La conducta del hombre que había comido pastel de choclo en su propia casa, le abre los ojos: lo que manda en política, advierte finalmente, es el "si te he visto no me acuerdo". Es el otro parlamentario de la circunscripción, el diputado Torres, quien finalmente deja en alto la dignidad y el sentido de la representación política. Aunque, cabe insistir, hay una inocencia, un candor pueblerino que se pierde definitivamente.

Instalados en un momento histórico concreto del que no se dan todas las señas -inicios del gobierno de Jorge Alessandri, último candidato de la derecha electo para el cargo en el siglo XX-, la cinta, sin embargo, propone una visión de la sociedad suficientemente abarcativa y compleja como para justificar el

\footnotetext{
${ }^{4}$ A este respecto cabe tener en cuenta las objeciones de Alan Knight a la utilidad descriptiva del binomio tradición/modernidad, tal como lo expresa en Revolución, democracia y populismo en América Latina. Santiago, Centro de Estudios Bicentenario y Pontificia Universidad Católica de Chile, 2005.
} 
carácter inaugural ya señalado. También, para abrir al lector/espectador un abanico de categorías y ejes identitarios: individuales y colectivos, buscados o recibidos por defecto. Qué se es, quién se es, a qué se pertenece, de qué se es distinto (o, dicho de otra forma, en oposición a qué se construye la propia identidad). Las preguntas pueden ser más, pero todas instalan a los personajes en espacios concretos y en dinámicas específicas, que se cruzan y encabalgan, problematizándolo todo. Ello, en el entendido de que "identidad" es un sustantivo huidizo, como ya a fines de los 60 lo constataba Erik H. Erikson: "Mientras más escribe uno de este tema, más se transforma la palabra en un término que designa algo tan insondable como ubicuo".

El presente texto propone que es posible detectar y estudiar la presencia de espacios identitarios en el cine chileno del último medio siglo. Ello, en el contexto de un cuadro interpretativo mayor: la posibilidad de comprender diversos aspectos de la historia, la sociedad y la cultura chilenas a través del cine -argumental- producido en el país. Tal propuesta se elabora desde la convicción de que existe una visión fílmica de la historia. Una convicción que no es un capricho ni un gesto de gran audacia: hace ya cuatro décadas Marc Ferro, miembro de los Annales y pionero del área, abordó una de las fuentes que nos hablan del hombre, subvalorada sin embargo por docentes e investigadores: las imágenes en movimiento, que a su juicio no entraban en el universo mental del historiador. Y no es que hoy se les considere tan llanamente una vía al conocimiento, pero resulta aceptable, o discutible al menos, la noción del cine como "contraanálisis" de las sociedades, desplegando en la pantalla ítemes e interrogantes que ni los propios creadores se plantearon. Otro tanto ha hecho su compatriota Pierre Sorlin, particularmente en lo relativo a lo que las películas dicen y sugieren respecto del tiempo en el que se hicieron ${ }^{6}$.

En EEUU se clavarían nuevas banderas: Ian Jarvie planteaba en 1988 que, "al favorecer la información emocional y visual sobre la analítica, las películas están alterando sutilmente nuestro parecer sobre el pasado", mientras Robert Rosenstone, nombre esencial en el área, nos ha recordado que las películas son un símbolo inquietante de un mundo posliterario ${ }^{7}$, que los historiadores harían bien en tomar la cámara y hacer historia con ella, que inventar la verdad histórica es un modo de dar sentido al pasado y que no sólo los historiadores profesionales merecen esta denominación (también cineastas como Chris Marker u Oliver Stone). Poniendo literalidades y fidedignidades al servicio de

\footnotetext{
${ }^{5}$ Erik H. Erikson: Identity. Youth and crisis. Nueva York, W.W. Norton, 1994, p. 9

${ }^{6}$ Cf. Marc Ferro: Historia contemporánea y cine. Barcelona, Ariel, 2000; El cine, una visión de la historia. Madrid, Akal, 2008. Pierre Sorlin: Sociología del cine. La apertura para la historia del mañana. México, FCE, 1985; "El cine, reto para el historiador" [en Revista Istor, Año 5, número 20, Primavera 2005, México D.F. En línea: http://www.istor.cide.edu/archivos/num_20/dossier1.pdf].

7 Cf. The American Historical Review, Vol. 93, No. 5, diciembre de 1988. De Rosenstone cabe destacar: El pasado en imágenes. El desafio del cine a nuestra idea de la historia. Barcelona, Ariel, 1997; La historia en el cine. El cine sobre la historia. Madrid, Rialp, 2014.
} 
una narrativa, del hallazgo de sentido y de la inteligibilidad, aproximaciones como ésta valoran, por lo mismo, la metáfora visual, la imaginación histórica e incluso la "invención de la verdad histórica", para usar una de las expresiones rosenstonianas más provocadoras. También, el efecto de inmersión, ese sumergirse en la historia a través de sus entresijos, sus pausas, sus emociones y sus temporalidades.

El ámbito hispanoparlante se ha hecho eco y ha seguidos sus propios derroteros. De ello dan cuenta, entre muchos otros, los trabajos de Josep María Caparrós, Gloria Camarero y Luis Ángel Hueso. Y en lo que toca a la escritura fílmica de la historia chilena queda muchísimo por andar, siendo un impulso significativo el que dio Joan del Alcàzar al abordar la filmografía del país entre 1970 y $1998^{8}$.

Finalmente, cabe explicar por qué este ensayo se basa en filmes argumentales, dejando de lado la rica tradición documental desarrollada en Chile y que tiene a figuras como Sergio Bravo, Ignacio Agüero y Patricio Guzmán entre sus realizadores más ilustres. Lo anterior tiene que ver, por un lado, con la especialización del autor, y por otro con un argumento que Natalie Zemon Davis ha expresado con nitidez:

\begin{abstract}
Escojo los largometrajes de ficción por constituir un caso más difícil que los documentales. Los largometrajes de ficción suelen describirse como hijos de la invención, sin conexión significativa con el mundo de la experiencia o el pasado histórico. En los estudios sobre cine, suele aplicárseles el término "filmes de ficción", destacando un contraste entre la imaginación libre de los largometrajes argumentales y la "verdad" de los documentales. Es precisamente esta dicotomía la que deseo poner en duda, no sólo porque existe un juego de invención -o destreza "ficticia"- en el cine documental, el docudrama y el cinéma vérité (como lo hay en los textos históricos en prosa), sino también porque los largometrajes de ficción pueden mostrar observaciones contundentes sobre procesos, relaciones y procesos históricos ${ }^{9}$.
\end{abstract}

Un viaje a Santiago, para retomar el hilo, autoriza algunas de las operaciones ya señaladas. $Y$ en lo que toca al presente texto, reverbera con particular notoriedad. Este largometraje, hoy olvidado y sin embargo homenajeado en su minuto por el más internacional y validado de los cineastas chilenos ${ }^{10}$, indaga en las adhesiones y pertenencias de individuos y colectivos de manera de tener un cuadro más amplio del Chile de su tiempo. Como el resto de los filmes que

${ }^{8}$ Cf. Gloria Camarero, Beatriz De las Heras y Vanessa De Cruz (eds.): Una ventana indiscreta. La historia desde el cine. Madrid, Ediciones J.C., 2008. Luis Ángel Hueso y Gloria Camarero (coord.): Hacer historia con imágenes. Madrid, Síntesis, 2014. Josep María Caparrós: 100 películas sobre Historia Contemporánea. Madrid, Alianza, 1997.

${ }^{9}$ Cf. Natalie Zemon Davis: Esclavos en la pantalla. La Habana, Icaic, 2012, pp. 18-19.

${ }^{10}$ En su ópera prima, Tres tristes tigres (1968), Raúl Ruiz sigue los pasos de un provinciano que circula por Santiago disponiendo de los fondos de una cooperativa llamada "Un viaje a Santiago". 
considera este ensayo, que tienen más de muestrario funcional que de canon o panteón, está visto necesariamente desde el presente. Y en tal condición nos habla de un modo particular. Cabe escucharlo, pues una escucha atenta permite atar cabos y unir puntos allí donde no teníamos previsto hacerlo.

\section{Los muchos}

El año 1960, inaugurado casi por el estreno del filme de Correa, vio también producirse un crimen que aún hoy -en buena medida gracias a la película basada en el caso, cuestión inhabitual en el caso chileno- es objeto de evocación, memoria y leyenda. En el poblado rural de Nahueltoro, $350 \mathrm{~km}$ al sur de Santiago, un campesino en estado de completa ebriedad, Jorge del Carmen Valenzuela, asesinó a la mujer con la que convivía, Rosa Rivas, así como a los cinco hijos de ésta. El caso, como muy pocos, sacudió a la sociedad chilena. Por su inusitada crueldad, en un principio, pero también por el cuadro social que reveló y por un sentido del suspenso judicial en virtud del cual el asesino, conocido a poco andar como el "Chacal de Nahueltoro", terminó enfrentando el pelotón de fusilamiento más de dos años después de ser detenido. En todo ese período había sido alfabetizado, convertido al catolicismo, educado en las minucias de la historia patria y en la adquisición de un oficio.

"Si en Chile habían ocurrido unos 50 fusilamientos a criminales, ¿por qué gran parte de la sociedad se estremeció e incluso hizo 'transferencia' con esa vida condenada, maldita (...) el día de su ajusticiamiento en 1963?”, pregunta la historiadora María Angélica Illanes. Y su respuesta es que el país vivía entonces la "época de la conciencia dolorida": "Un dolor por la pobreza y la miseria. Dolor y cargo de conciencia por la condena que la sociedad traía sobre algunos al nacer. Necesidad de purgar la culpa original del pecado histórico"11. En palabras de Illanes, "el pueblo pasó a ser el tema central de la sociedad chilena. Al nombrarse su presencia pobre, al estamparse su imagen blanca y negra con sus tablas, cartones y cordeles de ropa húmeda, el pueblo entró al texto, a la ciencia social y económica, a la prensa, a las Cámaras, al aula universitaria" $"$.

El pueblo, genéricamente: el proletariado (urbano o rural), la clase trabajadora (en singular o en plural), las masas populares, los desposeídos, los sectores populares. Varias son las designaciones. Y las experiencias asociadas a esta condición son, entre otras, para Julio Pinto, la pobreza ("Los sujetos populares son pobres, el pueblo es pobre. Dicha condición le ha otorgado a nuestra historia social un elemento de continuidad, una vivencia de la 'larga

${ }^{11}$ Cf. La batalla de la memoria. Santiago, Planeta/Ariel, 2000, pp. 146-147.

12 Ibid, p. 150. 
duración"”) y la dominación ("Las formas de subordinación dentro del mundo popular han adoptado diversas expresiones, desde aquellas que, producto de un bajo salario, restringen la posibilidad de los individuos de orientar su vida en el sentido que mejor les parezca, hasta la explotación más abierta y brutal") ${ }^{13}$.

El escenario así descrito entrañó una visibilización de cuestiones escondidas para quienes no las padecían. ¿Se hizo cargo el cine argumental chileno? En lo que toca al caso policial/judicial ya descrito, respondió con un filme que resultó ser, además de un éxito en boleterías, una obra fundacional del "Nuevo Cine chileno" (NCC), cuyo bautismo suele fijarse para el Festival de Cine de Viña del Mar: en octubre de 1969 se estrenó allí El Chacal de Nahueltoro, de Miguel Littin, que junto a Tres tristes tigres, de Raúl Ruiz, y Valparaíso, mi amor, de Aldo Francia, integrarían la "trinidad" de un cine cuyas películas tenían entre sí menos en común de lo que sugeriría el rótulo, sin olvidar el problema planteado por las que quedaron fuera ${ }^{14}$.

La cinta de Littin supone un alegato contra un sistema inicuo personificado en un "huacho" (un hijo de madre soltera, no reconocido por el padre) cuyo destino está signado por el abandono, el desarraigo y la ausencia de educación. Construida a partir de una minuciosa indagación en los expedientes judiciales y en la experiencia de periodistas que siguieron el caso, dibuja una biografía solitaria que sólo tras la comisión del crimen, del apresamiento y el inicio del juicio, se alinea con patrones de conducta y pautas identitarias específicas. Con todo, subsiste el foco en este "condenado de la tierra"15, en su condición de "huacho".

"Huacho" fue Bernardo O'Higgins, señalado desde hace al menos un siglo y medio como el "padre de la patria", y "huachos" eran la mayoría de los no pocos niños nacidos fuera del matrimonio en los años 60. La condición de tal, nos dice una interesante literatura a este respecto, es fundante de la propia sociedad chilena ${ }^{16}$. La cinta de Littin, plantean Cavallo y Díaz, "no sólo es la historia de un niño que creció con padres ausentes y se hizo hombre deambulando como un gañán, sino también la de un sujeto cuyo acto central -el principal de toda su vida- es el asesinato de cinco huachos y de su madre campesina. Y la explicación de ese crimen es, de nuevo, la condición de

${ }^{13}$ Cf. Julio Pinto y Gabriel Salazar: Historia Contemporánea de Chile II. Actores, identidad y movimiento. Lom, Santiago, 1999, p. 98.

${ }^{14}$ Cabe agregar que en el mismo festival se exhibieron cintas locales como Largo viaje (Patricio Kaulen) y Caliche sangriento (Helvio Soto), que sin embargo no han sido considerados como parte de este "nuevo cine". Este ítem es discutido en la obra ya citada de Cavallo y Díaz, así como en Verónica Cortínez y Manfred Engelbert: Evolución en libertad. El cine chileno de fines de los sesenta. Santiago, Cuarto Propio, 2014.

${ }^{15}$ La referencia al volumen del martinicano Frantz Fanon (1925-1961) no es casual, tratándose de uno de los autores preferidos por Littin, al menos en el tiempo en que estrenaba su película.

16 Cf. Sonia Montecino: Madres y huachos. Alegorías del mestizaje chileno. Santiago, Sudamericana, 1996. Gabriel Salazar: Ser niño "huacho" en la historia de Chile (siglo XIX). Santiago, Lom, 2007.

Araucaria. Revista Iberoamericana de Filosofía, Política y Humanidades, año 17, n 34. Segundo semestre de 2015. Pp. 329-351. ISSN 1575-6823 e-ISSN 2340-2199 doi: 10.12795/araucaria.2015.i34.15 
huacho". Con la complicidad, cabría agregar en función de lo visto, de una sociedad que no estuvo allí: en uno de los roles más extraordinarios provistos por el cine chileno, gentileza de Nelson Villagra, el asesino confeso dirá que nunca recibió "educación de naiden".

La condición de huacho se hace presente a su modo en Valparaíso, mi amor: Mario González, que tiene 6 hijos de los que sólo veremos 4, ha quedado viudo recientemente. Matarife de oficio, está cesante, y según contaría posteriormente, la extrema necesidad lo lleva a robar vacunos allí donde la ciudad-puerto se ruraliza. Después de que la policía -Carabineros de Chile- descubre a dos de sus hijos en flagrancia faenando un animal, la sanción judicial cae sobre Manuel, quien es condenado a 5 años y un día de cárcel. Sus hijos, de entre 3 y 14 años, han quedado "huachos" (aun si supervisados por la "comadre" de Mario, a su vez embarazada de éste). Empujados, según el caso, a la mendicidad, a los trabajos ocasionales, al robo o a una prostitución apenas disfrazada. A su modo, he escrito, porque la cinta de Francia hace explícita la conmiseración social en voz de un locutor de radio que llama a sus escuchas a tomar acciones para evitar mayores desgracias a estos menores sin padres. Pero también, acto seguido, deja ver la estigmatización, la condena por parte de ciertos vecinos que, como ellos, viven en casas pobres si es que no miserables, pero que pueden sentir una cierta "superioridad" por no estar, que se sepa, envueltos en delitos.

Dicho lo anterior, en la dialéctica de los pocos y los muchos, el segundo espacio es prácticamente copado por aquellos con recursos escasos -y ocasionalmente inexistentes- para la subsistencia. Los pobres -como pasa con casi cualquier otra categoría conducente a una definición identitario/ cultural- son tales no sólo en cuanto exhiben rasgos comunes observables y cuantificables. También lo son en la medida en que se oponen a quienes no lo son o actúan a nombre de éstos. De ahí que la "comadre" de Mario les manifieste a los carabineros que llegan hasta la casa de ambos a detener al segundo: "[ustedes están] pa' puro molestar a los pobres". Lo otro es asociar la conducta delictiva a la fatalidad y a la convicción religiosa, como cuando el mayor de los hijos e Mario recuerda que "mi papá decía que las vaquitas las hace Dios para que coman los pobres".

Los hijos de Mario González viven en lo alto de uno de los 45 cerros de Valparaíso, desde donde el mar se ve muy lejano. La película, que adopta en buena medida su punto de vista, apenas muestra el Océano Pacífico. Lejos de todo tarjetapostalismo, tampoco cede, sin embargo, a lo que después llamarían la porno-miseria: provee un sentido de verismo, de urgencia y de crítica social moldeado con las herramientas que proveen la estilística y la moral del neorrealismo de De Sica y del Visconti de Rocco y sus hermanos. Al igual que las señaladas cintas de Littin y Ruiz, al decir de una estudiosa del NCC, innovaron al ofrecer "el enfrentamiento directo a los problemas nacionales", así como por 
acercarse a una "idiosincrasia nacional perdida" desde los tiempos de El húsar de la muerte (1925, sobre el guerrillero independentista Manuel Rodríguez) ${ }^{17}$. El mismo texto, para mayor abundamiento, desestima una cinta anterior que dialoga en varios puntos con la de Francia, Largo viaje, atribuyéndole de paso un "paternalismo oficialista" (al momento de su realización, su director era presidente de Chile Films, cargo de confianza del gobierno democratacristiano de Eduardo Frei Montalva, electo por seis años en 1964).

Largo viaje, de Patricio Kaulen (1967), es una cinta coral avant la lettre que en primer lugar sigue los pasos de un pequeño de familia modesta cuyo hermano murió al nacer, y que atravesará el centro de la capital con las alitas de papel con que se veló a la criatura, intentando devolversélas con la ilusión de que así pueda volar al cielo. Retablo social que cruza los destinos de sujetos populares, acomodados y de una elástica clase media, asume el carácter misional de la trayectoria de su protagonista sin que eso suponga descuidar la severidad con que se observa a cada quien, en especial a los privilegiados, uno de cuyos representantes, un empresario que peina canas, es visto al inicio disparando a una paloma investida de simbolismos no sólo religiosos. Para mayor abundamiento, y en un hecho del todo significativo para el retablo acá dibujado, la familia del niño y otras que comparten un conventillo, viven a una cuadra de distancia, o algo más.

Llegados a este punto, cabría consignar la relevancia de las preguntas que interrogan por los puntos de vista de los relatos (el "desde dónde" se cuenta una historia), así como por el sujeto histórico retratado: si lo es en su exterioridad y en sus padecimientos, en su quehacer individual y familiar o derechamente en su ser colectivo. Miguel Littin se encamina a dar una respuesta en el Manifiesto de los Cineastas de la Unidad Popular. En la introducción a este documento programático hecho público a principios de diciembre de 1970, a poco de asumido Salvador Allende en el Palacio de La Moneda, se expresa que les ha llegado la hora a los cineastas, hijos más bien de la burguesía, pequeña o no, lo que el texto da entender pero no explicita: "Es el momento de emprender juntos con nuestro pueblo, la gran tarea de liberación nacional y de la construcción del socialismo". Y, como subrayando que se está entre dos veredas, agrega: "Basta ya de dejarnos arrebatar por las clases dominantes los símbolos que ha generado el pueblo en su larga lucha por la liberación". Pero acaso el cuarto punto del manifiesto propiamente tal, sea el que empuja hasta el límite el interés por ponerse al servicio de -y disolverse en- el más castigado de los estamentos sociales, que ha de ser el motor de la historia: "Entendemos por arte revolucionario aquel que nace de la realización conjunta del artista y

\footnotetext{
17 Zuzana M. Pick: "La imagen y el espectáculo cinematográfico" [en: Valjalo, David y Pick, Zuzana M.: 10 años de cine chileno, 1973/1983. Los Ángeles, Ediciones de la Frontera, 1984]. Citado por Cavallo y Díaz., op. cit., p. 34. Por su parte, Carlos Ossa Coo hablará de un "choque con la realidad". Cf. Historia del cine chileno. Santiago, Quimantú, 1971, p. 71.
} 
del pueblo unidos por un objetivo común: la liberación. Uno, el pueblo, como motivador de la acción y en definitiva el creador, y el otro, el cineasta, como su instrumento de comunicación"18. El artista, ha de inferirse, no es "el pueblo". Pero aspira a estar lo más cerca posible. O a superar su propia condición, como deja ver el director en una entrevista posterior:

El cineasta, llámese realizador, crítico o actor, de una u otra manera forma parte de la pequeña burguesía. Y esto lo tenemos que aceptar porque a fuerza de estar conscientes de que somos pequeño-burgueses podremos dejar de serlo. El cineasta tiene una educación determinada. En otras palabras, a diferencia del pueblo, está penetrado culturalmente y es ajeno a sus luchas. Su juicio, por lo tanto, carece de mayor valor porque ese juicio revela sus propias deformaciones ${ }^{19}$.

Con la transición democrática iniciada en 1990, el "sujeto popular" se verá más en la no ficción que en el cine argumental. Este último, hasta avanzados los 2000, ofreció un mapa fragmentado de espacios marginales que trasunta con nitidez su imaginario en el parecer de Toño, en Caluga o menta (Gonzalo Justiniano, 1990). En compañía de sus jóvenes y aburridos amigos, se le oye decir, tras la partida de un funcionario municipal que ha llegado a hablar con ellos: "Ahora recién se acuerdan de los locos, ahora que nos volvimos locos"20. También en el despliegue de identidades juveniles donde la pasión futbolera toma el lugar de la pasión política (El hombre que imaginaba, de Claudio Sapiaín, 1998; Azul y blanco, de Sebastián Araya, 2003), en figuras delictivas sin nexos con el tejido social (Cielo ciego, de Nicolás Acuña, 1998; Los debutantes, de Andrés Waissbluth, 2003) o en el narcotráfico visto, al decir de un crítico local, como un regreso a "la vieja fascinación de los chicos buenos por los chicos malos"21 (Mala leche, 2004).

Tal escenario supone un abismo respecto de las iniciativas fílmicas que a comienzos de los 70 dieron por sentado un impulso colectivo en el quehacer de los pobladores (Los testigos, de Charles Elsesser, 1971), o bien que dibujaron un fresco histórico/mítico en el que los campesinos han tomado la iniciativa

18 Cf. Pablo Marín: Texto y contexto: El Manifiesto de los Cineastas de la Unidad Popular y la construcción de una cultura revolucionaria. Tesis para optar al grado de Magíster en Historia. Santiago, Depto. de Historia, Facultad de Filosofía y Humanidades, U. de Chile, 2008.

19 "Primero hay que aprovechar el dividendo ideológico del cine". Revista Primer Plano, $\mathrm{n}^{\circ} 2$, Otoño de 1972 , p. 15. No ahonda el realizador en la paradoja que supone verter juicios que carecen de valor, dado el origen de quien los vierte.

${ }^{20}$ Como ocurre con términos históricamente polisémicos del habla chilena -como "huevón", que suscitó una entrada adicional en el diccionario de Rodolfo Oroz para describir un tratamiento de confianza propio de este territorio-, a partir de los años 80 el sustantivo "loco" pasó a ser también un tratamiento de confianza, ampliamente extendido en sectores populares y juveniles (v. gr.,"hola, loco", conocido en otras hablas) sin por ello perder sus demás acepciones, entre ellas la más antigua y universal, así como aquélla que sugiere un "reventón" por drogas o alcohol.

${ }^{21}$ Cf. Soto, Héctor: Una vida crítica. 40 años de cinefilia. Santiago, Aguilar, 2008, p. 321. 
revolucionaria, persuadidos de que la propiedad individual de la tierra ha de quedar atrás. Y finalmente, desarmados y desnudos, caen abatidos por la fuerza militar mientras un texto de Ernesto "Che" Guevara provee en pantalla un discutible consuelo, si es que no un desideratum: de los caídos también se hizo la revolución (La tierra prometida, de Miguel Littin, 1973, que no llegó a exhibirse en Chile antes del golpe militar).

\section{Los pocos}

Una de las historias laterales de Largo viaje, como ya se mencionó, es la de un matrimonio de buen pasar. Él es un empresario y ella, su atractiva y bien vestida esposa, parece llenar un vacío personal a través de su relación paralela con un hombre algo más joven que, a su vez, hace negocios con su marido. Este último no sólo es un gran tirador al blanco; también, un tipo despierto que advierte la traición y toma medidas al respecto.

Para fines de perspectiva histórica cabe subrayar dos elementos. Primero, la señalada proximidad física entre el conventillo donde nace y muere el "angelito", y el bien alhajado departamento del empresario, su cónyuge y su pequeño hijo, que cuentan con empleada doméstica y mayordomo: sin traicionar el verosímil cultural, dos mundos distanciados llegan a compartir un mismo plano en virtud de la convergencia de dos "momentos" urbanos en el centro de la capital. Diseñado a principios de los años 30, el Barrio Cívico, la más ambiciosa creación para realzar la institucionalidad el Estado, consideró la creación de una avenida (el actual paseo Bulnes) que uniría La Moneda, sede del Ejecutivo, con un nuevo Congreso Nacional que se edificaría 700 metros al sur del palacio, en el Parque Almagro. El proyecto global no se concretaría, pero sí la construcción de modernos edificios, residenciales y del aparato estatal, de fachada continua y homogéneos en su coronación. Desde los mismos años 30 se había iniciado una ininterrumpida migración desde los barrios "elegantes" del 900 (los de las calles República, Vergara, Ejército y hasta la propia Alameda) hacia el sector oriente de Santiago (comunas como Providencia, Las Condes y Vitacura). Pero por razones muy variadas "no todos" se habían mudado. Entretanto, la ciudad que a fines del XIX y principios del XX había albergado a los ocupantes de los antiguos rancheríos y cobijado la migración rural en "cités" y "conventillos"22, aún no completaba la retirada de estas soluciones habitacionales de su centro político, comercial y financiero.

${ }^{22}$ Cf. Armando de Ramón: Santiago de Chile (1541-1991): Historia de una sociedad urbana. Sudamericana, 2000, p. 145. Los conventillos son "edificios compuestos de habitaciones edificadas en torno a un pasadizo central o de un patio y destinadas a ser alquiladas individualmente a muchas familias". 
En segundo término están las cualidades del "sujeto oligárquico". En este caso, del empresario encarnado por Emilio Gaete, quien en los 60 y 70 ofició reiteradamente de "pije" (lo opuesto al "roto" y a todo otro etiquetado del sujeto popular): fue, por ejemplo, el compuesto Carlos Moller, padre de la protagonista de la serie televisiva Juani en sociedad (1967-1971). También, ministro de Obras Públicas del gobierno de Jorge Alessandri, el "gobierno de los gerentes", en El burócrata González (1964). Preste atención el lector/ espectador al modo en que pronuncia todas las "s" al final de las palabras -rasgo transversalmente inhabitual en el habla chilena de ayer y de hoy-, o cómo lleva sus trajes y su peinado impolutos.

El asentamiento de la identidad sociocultural puede tener muchas caras, siendo una de las más persistentes, además de las que exhiben personajes como los encarnados por Emilio Gaete, el recurso a la genealogía. En Los transplantados (1975), de Percy Matas ${ }^{23}$, el matrimonio Valenzuela Barceló, que optó por el destierro tras el triunfo de la Unidad Popular, recorre el cementerio parisino de Père Lachaise camino a la tumba del "tío Alberto" Blest Gana, autor de la novela chilena más reeditada del siglo XIX, Martín Rivas. Una vez ante la cripta, la esposa detalla sus lazos familiares con el escritor: "Pariente directo nuestro por el lado de los Gana. Es tío abuelo mío. Y por el lado de los Subercaseaux es pariente directo (sic)". Hasta que completa la secuencia: "Echeñique Ureta, Ureta Valdés, Valdés Cox, Cox Subercaseaux".

Contracara de la anterior, Diálogos de exiliados (1974), de Raúl Ruiz, muestra a Fernando Vial Errázuriz, otro expatriado en París, discursea sobre su árbol genealógico ante un periodista brasileño. "Vial por parte de padre, Errázuriz por parte de madre. Nosotros usamos dos apellidos en Chile", comenta. Y agrega:

Soy sobrino nieto del presidente Balmaceda, y por Errázuriz, bueno, Errázuriz es el que hizo Chile (...). Nosotros hicimos Chile y lo hicimos enorme. Te hablo de un Chile próspero, el Chile del cobre, del salitre, de las grandes fortunas. Bueno, sabíamos administrar el poder. Porque hace falta un ejercicio y cierta categoría moral, casi $^{24}$.

Sin perder de vista las dimensiones humorísticas instaladas por Ruiz a través de su personaje, en el que se tensionan el magnetismo de la cuna y la militancia de izquierda, se deja de manifiesto la pertenencia a un grupo, a una cultura, a una forma de ser que trasciende las adhesiones políticas. Por de pronto el apellido, como observan Luis Barros y Ximena Vergara, señala ya en la literatura chilena del 900 "a alguien que destacó socialmente y consiguió la estima de los demás". Es sinónimo de un prestigio que ha de ir multiplicándose

${ }^{23}$ La cinta adapta libremente la novela homónima de Alberto Blest Gana sobre expatriados hispanoamericanos en el París del 900, publicada originalmente en 1904.

${ }^{24}$ Cf. Pablo Marín: "Anotaciones -o apuntes- sobre las elites y el cine chileno", en Revista UDP, 09, 2012, p. 175.

Araucaria. Revista Iberoamericana de Filosofia, Política y Humanidades, año 17, no 34. Segundo semestre de 2015. Pp. 329-351. ISSN 1575-6823 e-ISSN 2340-2199 doi: 10.12795/araucaria.2015.i34.15 
al punto que el apellido que lo encarna llega a "convertirse en una especie de título de nobleza"25.

Aparte de complementarios, Diálogos de exiliados y Los transplantados son laboratorios de chilenidad a la distancia, donde el grupo más inmediato de pertenencia (familia, amistades, compañeros de militancia) brinda sentido y protección, exacerbando ciertos comportamientos y percepciones asumidos -habitualmentecomo tácticas de subsistencia. En el caso de Diálogos, particularmente, la experiencia traumática del exilio genera un registro de defensa en virtud del cual "el otro" es concebido como una amenaza. Asoma, en este contexto, un registro de supervivencia en el que se activan mecanismos de defensa primigenios que no tienen que ver con el yo ni con la integridad identitaria personal, sino con la mantención de la vida. En tal escenario, la figura de la horda es mucho más potente que la del individuo. Se plantea una "contraidentificación" que hace florecer las posiciones defensivas y, a la larga, la idea de encontrar en la afirmación de la identidad grupal una vía de subsistencia.

Así las cosas, en la capital francesa y más allá de la adhesión político-ideológica que se profese, el capital simbólico del origen vale poco. O nada. En esto, el patriarca de Los transplantados, que busca ganarse la vida en una ciudad donde ni su apellido ni sus relaciones abren puertas, es analogable al "cuico" -otrora "pije"-que protagoniza Música campesina (Alberto Fuguet, 2011). Que llegó a EEUU por amor y que se mantiene como puede, sin dominio del inglés y con mínimas calificaciones laborales: como jamás le pasaría en Chile, paga su alquiler limpiando baños.

"Creo que es fundamental", declaraba Ruiz en 1972, "realizar un cine que provoque una identificación o, mejor dicho, una autoafirmación nuestra a todos los niveles, incluso los más negativos. La función de reconocimiento (...) me parece la más importante indagación en los mecanismos reales del comportamiento nacional" 26 . Al año siguiente, entrevistado durante el rodaje de Palomita blanca, declararía que "me interesa mucho más el mundo del barrio, del cité, que el lado elegante". ¿Y cómo trata a "los de allá arriba" (el sector oriente de Santiago)?, le preguntan. "Muy simple. Pura descripción"27.

Conforme a esta lógica indagatoria ${ }^{28}$, la adaptación de la novela superventas de Enrique Lafourcade (que sólo se estrenaría en 1992) pone en escena un abismo social con aires de novela rosa, de melodrama folletinesco.

${ }^{25}$ Cf. El modo de ser aristocrático. El caso de la oligarquía chilena hacia 1900. Santiago, Eds. Aconcagua, 1978, p. 122.

26 "Prefiero registrar antes que mistificar el proceso chileno". Entrevista con S. Salinas, R. Acuña, F. Martínez, J.A. Said, H. Soto. Revista Primer Plano, nº4, Valparaíso, primavera de 1972.

27 "Ruiz, el obsceno palomo de Santiago". Crónica de Carlos Olivárez en La Quinta Rueda, n 7 , junio de 1973 .

${ }^{28}$ Esta lógica indagatoria, emparentada con la antropología y su observación participante, dejará huella en la realización local. Si bien Ruiz inicia en el exilio su "período francés", que toma distancia de los procedimientos usados en Chile hasta 1973, uno de sus alumnos, Cristián Sánchez, tomará en ciertos aspectos el relevo del maestro. Sánchez es autor de filmes como El zapato chino (1979), Los deseos concebidos (1982) y Cautiverio feliz (1998), filme histórico hablado principalmente en mapudungún, la lengua del pueblo mapuche, que por siglos resistió las embestidas del conquistador español.

Araucaria. Revista Iberoamericana de Filosofía, Política y Humanidades, año 17, n 34. Segundo semestre de 2015. Pp. 329-351. ISSN 1575-6823 e-ISSN 2340-2199 doi: 10.12795/araucaria.2015.i34.15 
María, la "Palomita", chica pobre que vive en un cité próximo al río Mapocho, conoce en el festival hippie de Piedra Roja a Juan Carlos, muchacho del "barrio alto" que maneja un Austin Mini y se resiste a las presiones familiares por hacer carrera y/o ganar dinero. Cinematográficamente, la mejor síntesis de la noción romántica de una relación interclases que ignora las distancias sociales, se ofrece en la imagen en que ambos se bañan desnudos en una playa solitaria: ella, que temía que Juan Carlos se riera de sus prendas interiores deterioradas por el uso, brinda por el contrario una voz off que se solaza del momento vivido y llama a que ricos y pobres se amen. Pero luego, en casa de él, "Palomita" se relaciona sólo con el servicio doméstico. Las amigas de Juan Carlos la llamarán "pelienta” (vulgar, poca cosa) y él mismo le dará la espalda, llegado el momento, para asumir acotadas lealtades de clase.

Palomita blanca es una radiografía, al tiempo que un dispositivo de observaciones frecuentemente cómicas, casi siempre crueles, sobre Chile y los chilenos. Puede pasar también, como pasa con otras cintas de Ruiz, que la solidaridad intraclase sea al menos un paréntesis favorable a la distensión en medio de divergencias ideológicas o de otra especie. Pasa en esta película, pero más y sobre todo en La expropiación (1971-73): el latifundista que decidió entregar su propiedad al Gobierno en medio de la Reforma Agraria, recibe a un funcionario de la estatal CORA (Corporación de la Reforma Agraria). En la cena de recepción descubren que ambos asistieron al tradicional colegio de los Padres Franceses de Alameda y echan a andar los códigos compartidos -alguna canción religiosa, el nombre de un profesor-, lo que integra al funcionario al universo cultural de esta familia latifundista ${ }^{29}$.

Entrada la noche, el funcionario se encierra en su habitación. Portando ahora una calavera en sus manos, se cuestiona, cual Hamlet, respecto de los escenarios políticos posibles:

Los tenemos agarrados [a la burguesía] con la Constitución. Lo mismo que ellos crearon, justamente eso, los paraliza. Total... (en voz muy baja)... Puta la huevá (golpetea luego, conflictuado, la calavera con sus dedos tras examinarla). Si se atreven a hacer cualquier cosa, recurrimos a las armas del pueblo. ¡Recurrimos al pueblo, recurrimos a las masas! ¡Nos veremos obligados a recurrir a las masas! Cualquier cosa que se les ocurra hacer... (pausa)... Nos veremos obligados a recurrir a las masas. A las masas, señores, eso es.

El funcionario se sabe, por origen, "uno de ellos", pero por convicción ha elegido estar junto a los desposeídos y los explotados. Más aún, piensa que su condición de burgués lo ayuda a manejar mejor que nadie los códigos que la burguesía ha creado y que ahora -en su apreciación- se vuelven contra ella.

${ }^{29}$ Cf. Pablo Marín: "Mito e historia en La expropiación” [en De los Ríos, Valeria y Pinto, Iván (eds.): El cine de Raúl Ruiz. Fantasmas, simulacros y artificios. Santiago, Uqbar, 2010]. 
Pero antes de que acabe de expresar sus sentimientos, un grupo de campesinos, antorchas en mano, llegan a la casa del fundo y exigen hablar con él. No tienen su origen, como el dueño del fundo. Pero son los suyos y, dado que quienes recorren el mismo camino son compañeros, el trato de "compañero" horizontaliza la relación. Los campesinos le reprochan ir a hablar con los patrones antes que con ellos y él les explica que es el procedimiento que corresponde y pide apego al programa de Gobierno, a no hacer olas y no darle municiones a la oposición:

El Gobierno no puede expropiar los fundos de un viaje, pues compañero. No tiene capacidad económica, no tiene capacidad técnica. Así es que yo les ruego que se vayan tranquilos, mas bien yo les ordenaría que se fueran tranquilos para sus casas porque la verdad es que están entorpeciendo la labor de la Corporación de Reforma Agraria y están, además, creando un clima que no es propicio para el gobierno, sobre todo cuando estamos a un paso de las elecciones y sobre todo en el momento en que el enemigo está diciendo que somos los que alteramos el orden, que somos los que establecemos la violencia, etc., etc. Eso sería todo, compañeros. Buenas noches.

"Les ruego (...), más bien les ordenaría”... Más allá de que esta corrección sobre la marcha pueda corresponder al estilo improvisador de Ruiz -que acostumbraba dar el "pie" a sus actores, tras lo cual estos creaban sus parlamentos-, expresa la situación de alguien que, por razones operativas, está en condiciones de dar órdenes para el buen término de un procedimiento sancionado por la ley, pero que también trata con sus "compañeros", quienes se alejan mientras se escuchan sonidos esperpénticos, como si se anunciaran fantasmas. Acto seguido, para rematar su crisis de identidad, el funcionario vuelve al salón de la casa patronal. Y habla golpeado:

Don Nemesio, quiero que me escuche. Tengo que decirle algo muy claramente y a todos ustedes. No crean ustedes que me van a amedrentar, no voy a aceptar ningún tipo de provocación. Vengo llegando en este momento de una reunión que he tenido allá con los campesinos. Les he explicado claramente lo mismo. En todo caso, quiero decirles a ustedes que ellos tienen mucho más derecho a reclamar y a tomar actitudes violentas porque ellos, por último, están defendiendo su vida y su pan, y ustedes están defendiendo exclusivamente sus privilegios, sus posesiones. ¡Reaccionarios! ¡Momios! ¡Carajos! Seguiré cumpliendo con mi obligación, (...) y ahora les voy a decir algo: quiero que todos... no sólo quiero, se los voy a decir muy claramente, les exijo que se vayan todos tranquilamente a sus respectivas tumbas ${ }^{30}$.

En un registro y con un tono completamente distintos, Machuca (Andrés Wood, 2004) aborda la relación de dos niños próximos a iniciar la adolescencia:

${ }^{30}$ El presente análisis reformula el desarrollado por el autor en Texto y contexto, op cit., pp. 56-57. 
uno estudia en un distinguido, aunque ficticio, colegio de la comuna santiaguina de Vitacura, el otro vive en una población "callampa" próxima al colegio y se ha incorporado como alumno en virtud de una política de integración impulsada por el propio establecimiento. Basada en la experiencia escolar del realizador -ex alumno del colegio St. George-, la cinta muestra a los dos muchachos, Machuca e Infante, desarrollando afectos mutuos y conociendo el mundo del otro. Todo termina, sin embargo, la mañana del 11 de septiembre de 1973, día del derrocamiento de Salvador Allende.

Infante, el muchacho de familia burguesa y "buen apellido", ha cruzado el Mapocho para ir al encuentro de su amigo, moreno y proletario. Sin embargo, es víctima de los rigores de la represión desplegada por una patrulla militar. Ahí es cuando le pide a un soldado, que pretende llevarlo consigo, que lo mire bien. Que le mire la cara y vea cómo anda vestido. Que advierta que él no pertenece, finalmente, a la población donde se encuentra. El soldado se da cuenta y lo deja ir. Cada quien ha oído los tambores de su tribu al cierre de una película que da cuenta de la atávica división social entre "peras y manzanas"31.

Si la historia del cine chileno está atravesada por personajes "castigados por la pobreza", como afirman Cavallo, Douzet y Rodríguez ${ }^{32}$, para el mismo trío de autores los personajes "castigados" estaban ya menos presentes en los 90. En el nuevo siglo, que ha simplificado, democratizado y multiplicado la realización local (el público es otro tema), el fenómeno se profundiza. Guionistas y directores "viven en mundos muy aislados", comentaba Orlando Lübbert en 2009, cuando dirigía la carrera de cine en la U. de Chile. Y agregaba el guionista y director de Taxi para 3 (2001): "A muchos de mis alumnos les pregunto, “¿qué les ha pasado en la vida?”, y se dan cuenta de que son parte de una clase hiperprotegida, encerrada en sus seguridades"33.

Loanteriorbien podríavincularse con elmundo sociocultural(re)descubierto en años recientes a partir de una actitud introspectiva y una política que se evoca: que puede ser mar de fondo, pero rara vez el tema, que justifica aquello que se daría en llamar el "ombliguismo" del cine chileno contemporáneo. De ello hay varios ejemplos, entre los que destacan Las niñas (2007) y Zoológico (2011), de Rodrigo Marín: un cine de espacios físicamente cerrados y socialmente acotados; de conflictos silenciados y de incestos sugeridos. Otro tanto, aunque con otros horiozntes, hizo La nana (Sebastián Silva, 2009), que desnuda, literalmente, la figura del patrón y que se sumerge en variados silencios asociados al servicio doméstico y a su lugar en la mecánica de cierta élite local del siglo XXI. Ya antes, en 2005, año de inflexión en cuanto a variedad, temática y número de las producciones locales, era visible que directores y guionistas preferían

\footnotetext{
31 Joan del Alcàzar: Chile en la pantalla, op. cit., pp. 206-212.

${ }^{32}$ Cf. Huérfanos y perdidos. Relectura del cine chileno de la transición. Santiago, Uqbar, 2007, p. 114.

33 “El cine chileno le teme a la emoción”. Entrevista con el autor. La Tercera, Santiago, 26/07/09.
} 
abordar mundos conocidos antes que asumir el examen culposo de universos ajenos. Así lo evidenció En la cama (Matías Bize, 2005), protagonizada por dos compañeros de lecho que recién se conocen. El varón de la pareja, en cierto momento, se burla privadamente de las costumbres de los "rotos": le cuenta a su ocasional pareja que la hija el conserje del edificio donde vive se llama Ledidí Carrasco. No Lady Di, sino Leididí. En tanto, eso de que "los cuicos también lloran" - comentario que circuló respecto de su novela Mala onda (1991)-es visible en Se arrienda (2005), el debut tras la cámara de Alberto Fuguet. Contraparte pop de las anteriores es la comedia Qué pena tu vida (Nicolás López, 2010), cuyo éxito comercial dio pie a una trilogía que completan Qué pena tu boda (2011) y Qué pena tu familia (2012). La crítica de las dos primeras destacó, ante todo como handicap, el ambientarse "de Plaza Italia para arriba"34. Nada más útil que decir respecto de esta saga cómicoromántica sobre un publicista tontorrón y enamoradizo.

\section{Multiplicidades y disociaciones}

No puede sino haber de "los unos y los otros" en la cinematografía chilena de más de medio siglo. Con solo establecerlo, eso sí, poco y nada se avanza. El punto pasa por que cuestiones como la "explosión de identidades" (sexuales, políticas, religiosas, deportivas, tribales) visible a mediados de los $90^{35}$ han hecho exigible problematizar ejes identitarios como los ya señalados, que se daban por sentados o que se consideraban unívocamente, sin tener en cuenta el modo en que distintos ejes pueden operar en simultáneo, con consecuencias muy diversas. Que allí donde los personajes dejan de manifiesto sus pertenencias y adhesiones, otros factores pueden ingresar y desarmar el naipe.

El ítem etáreo, para entrar en terreno, puede funcionar como constante o al menos como grupo de control: definir a los individuos "por defecto" en función de la edad que los toca tener y de las adhesiones o pertenencias que aquello hace posible, puede proveer valiosos acercamientos a lo que la historia cultural solía llamar imaginarios o mentalidades, formas impersonales del pensamiento y modos compartidos de enfrentar la socialización y la experiencia. Dentro del período que aborda este ensayo, la segunda mitad de los 60 marca el despuntar de una generación en particular, de la "juventud de todos los tiempos", como la llamó un cineasta chileno (de la generación de los 70) ${ }^{36}$. Cabe insistir: el medio

${ }^{34}$ La Plaza Baquedano, que los santiaguinos normalmente confunden con la Plaza Italia, muy próxima a ella, es el lugar donde se celebran los triunfos deportivos y que oficia de frontera entre las comunas de Santiago (centro) y Providencia. Por lo anterior es la línea divisoria entre el "abajo" y el "arriba" de la capital.

35 Una perspectiva global del tema identitario en Chile puede encontrarse en Jorge Larraín: Identidad chilena. Santiago, Lom, 2001.

${ }^{36}$ Material editado de entrevista del autor con el cineasta Ricardo Larraín publicada en Revista 
social, la fe religiosa, las simpatías políticas, etc., moldean y condicionan como antes. O más que antes. Pero la observación del sujeto adolescente y juvenil en los filmes de esos años, y hasta 1973, da suficientes indicios de la configuración de una cultura de alcances transversales sostenida en la recurrencia de conductas, prácticas y visiones de mundo.

Así pasa en Voto más fusil (1971), ambientada en los días previos a la elección que dio el triunfo a Salvador Allende, el 4 de septiembre de 1970. En la mesa de un publicista cumpleañero que festeja los 40 se instala la tensión. El padre del protagonista, un militante comunista que también cumple 40 años, pero "en la izquierda", evoca los tiempos del Frente Popular, la alianza del PC chileno y el centrista Partido Radical que hizo posible la elección de Pedro Aguirre Cerda como Presidente, en 1938. Sin embargo, el festejo de este "viejo bolche" será aguado por un amigo del cumpleañero, militante del entonces clandestino Movimiento de Izquierda Revolucionaria (MIR) 37: "si usted me habla de gente muerta, es porque usted está muerto", le espeta a otro comunista veterano presente en la celebración, que algo le había dicho respecto de Lenin y que más tarde lo tratará de "pije aventurero".

Episodios como éste darán cuenta de al menos dos tensiones que el cine puede iluminar tanto o más que la literatura o la historiografía. En primer término, y en un espacio sociocultural acotado pero significativo, está la brecha entre comunistas y miristas $-\mathrm{y}$ por esta vía, entre "reformistas" y "revolucionarios"-, especialmente en dos cintas de Helvio Soto: la recién mencionada y Metamorfosis del jefe de la policía política (1973). En ambas, los militantes y funcionarios comunistas son gente más bien mayor, disciplinada, estructurada, legalista y aburrida. Los miristas, en cambio, son jóvenes, audaces, rebeldes, bien vestidos y bien parecidos. Tamaña distinción es funcional al thriller político que Soto dibujó en ambos casos y se encamina a dejar de manifiesto no sólo la cuestión generacional, sino también la raíz social de estos jóvenes revolucionarios: gente "de buena familia", como los retrata un juez de la República.

En segundo lugar, se tiende una brecha generacional a secas. Es cierto que en los 60 la idea ambiental de revolución, entendida como transformación radical en cualquier ámbito y/o como una aceleración de la historia, se asoció en buena medida a lo juvenil. Ser joven y no ser revolucionario, en la visión de Salvador Allende, sería "una contradicción casi biológica" (cuestión que un colaborador le recordaría en los minutos previos al bombardeo de La Moneda en Allende en su laberinto, de Miguel Littin, 2014). Ser joven y encarnar una

\footnotetext{
Qué Pasa, 10/01/1998.

37 Para una historia de este movimiento, que nació de una escición del Partido Socialista, en 1965, que defendió la vía armada para la conquista del poder y que presumió en 1970 de estar a la izquierda de la Unidad Popular, de la que no formó parte, cf. , Eugenia Palieraki: ¡La revolución ya viene! El Mir chileno en los años sesenta. Santiago, Lom, 2014.
} 
"revolución de las flores", donde todos pintan todas las bicicletas blancas para que ninguna le pertenezca a nadie en particular, es parte de un mismo gesto en New love (1968), de Álvaro Covacevich. También puede discutirse de la revolución en una boîte mientras se baila un ritmo de moda, como hacen los protagonistas de la comedia romántica Lunes $1^{\circ}$, domingo 7 (Helvio Soto, 1968). Que quede claro, como señala uno de los protagonistas de esta última, que "un viejo de 40" no podría entender las motivaciones ni las angustias de estos personajes ni de la época en que viven. Algo semejante, aunque en sentido contrario, le pasa al matrimonio que estelariza La casa en que vivimos (Patricio Kaulen, 1970). Padres de un universitario políticamente "comprometido" y de una muchacha que sólo piensa en fiestear, ambos ven cómo la lucha de décadas por materializar el "sueño de la casa propia" -aspiración sentida de un funcionario radical como el patriarca familiar- es una batalla que sus vástagos apenas comprenden. Y que no necesariamente valoran. Acaso porque, como reza el proverbio árabe citado alguna vez por Marc Bloch, se parecen más a su tiempo que a sus padres.

La pertenencia a una categoría es un anclaje en el mundo y perderla, o cambiarla por otra, entraña alteraciones de distinto orden. En ciertos casos, el encabalgamiento de identidades puede asumirse sin trauma ni fisuras aparentes, como deja ver la protagonista de Play (Alicia Scherson, 2005), que ejerce de empleada doméstica, que habla mapudungún -la lengua de los aborígenes mapuches- y que provista de unos grandes audífonos recorre en transporte público la capital, desde las altas cumbres hasta los bajos fondos. Pero también podemos encaminarnos al sicodrama. Lo supo o lo intuyó Raúl Ruiz, que llevó a algunos de sus personajes en direcciones insospechadas. Así, en El realismo socialista (1973), un publicista de derecha llega a convertirse en un ferviente activista de izquierda, mientras un obrero pasa de la izquierda dura hasta posiciones totalmente opuestas. Y en 2008 firmará Ruiz el guión de Secretos, dirigida por Valeria Sarmiento. La cinta, una comedia engañosamente ligera, sigue los pasos de Atalíbar, ex militante socialista que vuelve del exilio: sus viejos camaradas lo llaman cariñosamente "traidor", apodó que se ganó en tiempos de la Unidad Popular, cuando se infiltró en el Partido Radical (centroizquierda), después en la Democracia Cristiana (centro), luego en el Partido Nacional (derecha) y en el movimiento Patria y Libertad (ultraderecha). ¿Quién es Atalíbar? ¿A qué pertenece? Difícil saberlo. Si él mismo se lo preguntara, como el protagonista de Consuelo (Luis R. Vera, 1989), tal vez se respondería lo mismo que se responde, en sueco, este fotógrafo exiliado en Estocolmo y próximo a volver a su querido Valparaíso: "Ya no sé cuál es mi identidad"38.

${ }^{38}$ Este ítem, a su vez, está presente en una película posterior de Luis R. Vera: Bastardos en el Paraíso (2000). Ambientada en Estocolmo, sigue los pasos de un hijo de exiliados. Sus padres no hablan sueco y él es parte de una pandilla. 
Y podría, como de hecho ocurre en la filmografía de Pablo Larraín, que la respuesta esté derechamente en la disociación mental, en el desequilibrio o el fin del juicio de realidad. En Tony Manero (2008), ambientada en el Santiago de fines de los 70, el protagonista es un ángel de la muerte, un bailarín que no va de represor ni resistente a la dictadura militar, sino de conciencia tanática, si tal cosa pudiera decirse. Raúl Peralta es un antihéroe con trastorno grave de la personalidad. No actúa como quien sufre y hace sufrir: simplemente, mata y baila sin conflicto aparente. Sus propios gestos dibujan una impulsividad que está en el centro de su conducta. Y, finalmente, una locura que lo exime de culpa: que da cuenta del horror sin necesidad de hacerse cargo.

Algo en esa línea expresa Post mortem (2010), el siguiente largometraje de Larraín, que junto a la anterior y a $N o$ (2010) darán forma a un tríptico sobre la historia chilena reciente. El mismo protagónico de Tony Manero (Alfredo Castro) da vida a Mario Cornejo, un funcionario de la morgue capitalina en los días inmediatamente previos y posteriores al golpe de 1973. Un disociado, nuevamente, a través de cuyos ojos nos asomaremos al violento acomodo que supondrá el no menos violento cambio de régimen: así, su médico en jefe transita del radicalismo pro Ho Chi Minh a una perfecta colaboración con los militares que toman el control en su repartición. Y en su caso, en el metafórico plano secuencia que pone fin al filme, lo veremos bloqueando pesadamente el único acceso al escondrijo de un militante de izquierda, sellando su destino sin que el afectado -ni el propio espectador- haya sospechado.

\section{El refugio de la identidad esencial}

La pregunta por quién se es y por dónde inscribirse en el seno de la vida social no siempre se responde fácilmente. Pero las películas locales seguirán ensayando respuestas. Algo que también han hecho y vuelto a hacer es rendirse ante una idea genérica y englobante de "chilenidad". Ante la tentación de una "canción para todos", como reza el subtítulo de Ayúdeme usted, compadre (Germán Becker, 1968), que se mantendría por más de 30 años como la más taquillera de las producciones locales. Esta sucesión de viñetas y postales de un Chile pujante ha sido cuestionada en su propia calidad de largometraje argumental ${ }^{39}$, sin perjuicio de que una investigación reciente la redima en este punto, atribuyéndole una filiación por el lado de la revista musical estadounidense y calificándola provocativamente como la película más política del período, en tanto expresión desembozada del programa democratacristiano

${ }^{39}$ Cf. Cavallo y Díaz, op. cit., p.244. Los autores afirman que "la sucesión de secuencias sin continuidad narrativa ni espacial convierte a la película en una sucesión de viñetas en movimiento... pero inmóviles, clavadas en la historia y el espacio".

Araucaria. Revista Iberoamericana de Filosofía, Política y Humanidades, año 17, no 34. Segundo semestre de 2015. Pp. 329-351. ISSN 1575-6823 e-ISSN 2340-2199 doi: 10.12795/araucaria.2015.i34.15 
en curso $^{40}$. Ello, desde la primera secuencia, que instala a un grupo de pasajeros chilenos viajando de Nueva York a Santiago con la seguridad provista por la aerolínea estatal LAN Chile e interpretando, a coro, la tonada "Chile lindo", de Clara Solovera:

Chile, Chile lindo, como te querré

que si por vos me pidieran

la vida te la daré

Esta "película fascista", como la llamaría contemporáneamente un Ruiz que usaba el término menos seguido que lo que acostumbraba la izquierda de su época, no dejó mayor huella en la realización local, pese a su éxito arrasador. Sin embargo, su chilefilia rampante hizo casi inevitable recordarla con motivo del estreno reciente de dos filmes estelarizados por el comediante, imitador y figura de TV Stefan Kramer: Stefan vs. Kramer (2012) y Ciudadano Kramer (2013). El primero rompió los récores históricos de asistencia -para películas nacionales y extranjeras-, proveyendo un set de imitaciones de personajes mediáticos, incluido el propio Presidente, Sebastián Piñera. El segundo tuvo una particularidad y una intención: hacer del apoliticismo el camino a un nacionalpopulismo de largo alcance: Kramer, que en ambos casos hace de sí mismo, se convierte en precandidato presidencial y transforma a un dirigente social de la austral región de Aysén en un ícono de unidad, en una "voz del pueblo" ajena a los "arreglines" de los políticos profesionales. La película termina con el protagonista declamando y luego abrazando al dirigente mientras una bandera chilena flamea de fondo en una pantalla gigante.

Si un asesor de la oposición a Augusto Pinochet se preguntó en No (Pablo Larraín, 2012) “¿qué es más alegre que la alegría?”, a propósito de la premisa de la campaña opositora en el plebiscito que decidió el destino de la dictadura militar, en 1988, ahora la pregunta sería, “¿qué es más chileno que Chile?”.

${ }^{40}$ Cf. Verónica Cortínez y Manfred Engelbert: Evolución en libertad, op. cit., pp. 293-438. 


\section{Referencias bibliográficas:}

Alan Knight: Revolución, democracia y populismo en América Latina. Santiago, Centro de Estudios Bicentenario y Pontificia Universidad Católica de Chile, 2005.

Armando de Ramón: Santiago de Chile (1541-1991): Historia de una sociedad urbana. Sudamericana, 2000.

Ascanio Cavallo y Carolina Díaz: Explotados y benditos. Mito y desmitificación del cine chileno de los 60. Santiago, Uqbar, 2006.

Ascanio Cavallo, Pablo Douzet y Cecilia Rodríguez: Huérfanos y perdidos. Relectura del cine chileno de la transición. Santiago, Uqbar, 2007.

Carlos Ossa Coo: Historia del cine chileno. Santiago, Quimantú, 1971.

Gabriel Salazar: Ser niño "huacho" en la historia de Chile (siglo XIX). Santiago, Lom, 2007.

Gloria Camarero, Beatriz De las Heras y Vanessa De Cruz (eds.): Una ventana indiscreta. La historia desde el cine. Madrid, Ediciones J.C., 2008.

Jorge Larraín: Identidad chilena. Santiago, Lom, 2001.

Julio Pinto y Gabriel Salazar: Historia Contemporánea de Chile II. Actores, identidad y movimiento. Lom, Santiago, 1999.

Luis Barros y Ximena Vergara: El modo de ser aristocrático. El caso de la oligarquía chilena hacia 1900. Santiago, Eds. Aconcagua, 1978.

Luis Ángel Hueso y Gloria Camarero (coord.): Hacer historia con imágenes. Madrid, Síntesis, 2014.

Marc Ferro: Historia contemporánea y cine. Barcelona, Ariel, 2000

Marc Ferro: El cine, una visión de la historia. Madrid, Akal, 2008.

María Angélica Illanes: La batalla de la memoria. Santiago, Planeta/Ariel, 2000.

Natalie Zemon Davis: Esclavos en la pantalla. La Habana, Icaic, 2012.

Pablo Marín: Texto y contexto: El Manifiesto de los Cineastas de la Unidad Popular y la construcción de una cultura revolucionaria. Tesis para optar al grado de Magíster en Historia. Santiago, Depto. de Historia, Facultad de Filosofía y Humanidades, U. de Chile, 2008.

Pablo Marín: "Mito e historia en La expropiación". En De los Ríos, Valeria y Pinto, Iván (eds.): El cine de Raúl Ruiz. Fantasmas, simulacros y artificios. Santiago, Uqbar, 2010.

Pablo Marín: Anotaciones -o apuntes- sobre las elites y el cine chileno, [en "Revista UDP", 09, 2012].

Pierre Sorlin: Sociología del cine. La apertura para la historia del mañana. México, FCE, 1985 
Robert Rosenstone: History in images/History in words: Reflections on the possibility of really putting history onto film. [en The American Historical Review, Vol. 93, No. 5, diciembre de 1988, pp. 1173-1185].

Robert Rosenstone: El pasado en imágenes. El desafio del cine a nuestra idea de la historia. Barcelona, Ariel, 1997

Robert Rosenstone: La historia en el cine. El cine sobre la historia. Madrid, Rialp, 2014.

Sonia Montecino: Madres y huachos. Alegorías del mestizaje chileno. Santiago, Sudamericana, 1996.

Verónica Cortínez y Manfred Engelbert: Evolución en libertad. El cine chileno de fines de los sesenta. Santiago, Cuarto Propio, 2014.

Zuzana M. Pick: La imagen y el espectáculo cinematográfico [en: Valjalo, David y Pick, Zuzana M.: 10 años de cine chileno, 1973/1983. Los Ángeles, Ediciones de la Frontera, 1984]. 
